\title{
Nutrients, Phytochemical Composition and Antioxidant Analysis of Selected Agricultural Wastes as Potential Livestock Feed Ingredients
}

\author{
${ }^{* 1}$ S.O. Akiode, ${ }^{2}$ A.E. Fadeyi, 2O.E. Falayi, 2 S.A. Emmanuel and 1P.C. Onyenekwe \\ ${ }^{1}$ Biotechnology Advanced Research Centre, Sheda Science and Technology Complex, P.M.B. 186 Garki, Abuja, Nigeria \\ ${ }^{2}$ Chemistry Advanced Research Centre, Sheda Science and Technology Complex, P.M.B. 186 Garki, Abuja, Nigeria \\ [ ${ }^{*}$ Corresponding Author: E-mail: akiode_ola@yahoo.com, so.akiode@shestco.gov.ng; : : +2348039477853, +2347050926596]
}

\section{ABSTRACT}

This study was carried out to analyse the proximate, phytochemical composition and antioxidant activity of three agricultural wastes (Melon husk, moringa pod and mango endocarp).The proximate parameters of the samples were determined using the standard analytical method of Association of Official Analytical Chemists. The antioxidant activity was determined by the radical scavenging activity of the methanol extract of samples against DPPH (Sigma Aldrich) by UV-Visible Spectrophotometer at 517 $\mathrm{nm}$. The results revealed that the three samples are high in crude fibre: $51.61 \%$ (melon seed husk), $58.10 \%$ (moringa pod) and $49.47 \%$ (mango endocarp). The crude protein content of the samples ranged from $3.45 \%$ to $12.22 \%$. The mineral analysis showed that melon seed husk contains; $\mathrm{Ca}$ (14.94 $\mathrm{mg} / \mathrm{kg}), \mathrm{Mg}(52.26 \mathrm{mg} / \mathrm{kg}), \mathrm{Fe}(21.2 \mathrm{mg} / \mathrm{kg}), \mathrm{P}(106.7 \mathrm{mg} / \mathrm{kg}), \mathrm{Zn}(0.70 \mathrm{mg} / \mathrm{kg}) ;$ moringa pod contains Ca (243.95 mg/kg), Mg (61.44 mg/kg), Fe (3.60 mg/kg), P (33.75 mg/kg), Zn (0.35 mg/kg); mango endocarp; $\mathrm{Ca}(6.14 \mathrm{mg} / \mathrm{kg}), \mathrm{Mg}(13.00 \mathrm{mg} / \mathrm{kg}), \mathrm{P}(24.25 \mathrm{mg} / \mathrm{kg}), \mathrm{Zn}(0.17 \mathrm{mg} / \mathrm{kg})$. Phytochemical screening of the three samples showed small amount of antinutrient like saponin, oxalate, flavonoid etc. The results obtained from this study indicate that the agricultural wastes may serve as energy and mineral supplier and thus may be utilized as a potential feed ingredient in livestock feed, coupled with their low antinutrient content.

Keywords: Antioxidant, Mango endocarp, Melon husk, Moringa pod, Nutritional

\section{INTRODUCTION}

Agricultural wastes are all forms of plantderived or animal-derived materials that are considered useless either because they have no known positive economic importance or because they are not grown/raised for any specific purpose. These include woods, herbaceous plants, crops and forest residues, animal wastes and so on (Adeyi, 2010). In Nigeria, large quantities of these wastes are produced annually and are vastly underutilised. Many agricultural products such as soybean and groundnut used as ingredients in the formulation of feed for livestock are also stable food for many people (Ogbe and George, 2012). In Africa corn/maize is a staple food for many people and soybean is not readily available, as soybean is utilized for making soybean milk which is taken as fresh drink by many people. Soybeans are not readily available (Mutayoba et al., 2011). Thus, there is competition for these feed ingredients between animals and humans, making them more expensive and their inclusion in poultry diet also increases the cost of poultry production (Mutayoba et al., 2011). Under normal conditions the cost of poultry feed have been reported to account for over $70 \%$ of the total cost of poultry production (Mutayoba et al., 2011; Ogbe and George, 2012). Consequently, a search for alternative sources of raw material for livestock feed will go a long to mediate the competition between human food sector and animal food sector without compromising quality (Ogbe and George, 2012). Nutritionists and research scientists are turning attention to alternative sources of feed ingredients such as agricultural and industrial by-products. An agrarian country like Nigeria is rich in many agricultural by- products, majority of which are laying waste as litters in the environment.

Melon (Citrullus lanatus) is a cucurbit crop that belongs to the family cucurbitaceae. Melon seeds 'Egusi' are grown, harvested and processed by removing the seeds from the fruits followed by washing and sun-drying. The flesh is inedible but the seeds are valuable in 
Africa. They found usage either as food supplement (soup condiment) or also for medicinal purposes (Abdulrazak et al., 2014). They are used in the treatment of urinary tract infection, hepatic congestion, intestinal worms and abnormal blood pressure (Moerman, 1998). Melon husks are shells that are discarded after shelling of melon seeds. Melon husk is a lignocellulosic plant biomass and a waste product from the food industry, having proteins, celluloses and lipids coated on its surface (Adelagun et al., 2014). Mango (Mangifera indica L.), is an Indian or a tropical evergreen (deciduous) tree which produces green fruits when unripe but green to light green or yellowish to reddish (sweet, juicy and succulent) fruits when ripe (Morton, 1987; Bally, 2006; Seifu, 2010). Among the major producers of mango in the World, Nigeria ranks $8^{\text {th }}$ (Morton, 1987; FAO, 2004; Yusuf and Salau, 2007), and Benue ranks first (1st) in the league of states that produce mangos in Nigeria (Yusuf and Salau, 2007). The other mango producing states in Nigeria include; Jigawa, Plateau, Kebbi, Niger, Kaduna, Kano, Bauchi, Sokoto, Adamawa Taraba and the Federal Capital Territory (FCT) (Yusuf and Salau, 2007). Mango pulp can be consumed at ripeness or in immaturity although most of the fruit is eaten fresh, and a wide range of foods can be prepared with the pulp (Ribeiro and Schieber, 2010). It can be canned, frozen as concentrates, mashed, dehydrated, minimally processed, or prepared as juices and jams (Masibo and $\mathrm{He}, 2009$ ). It is estimated that 35$60 \%$ of the fruit is discarded as waste after processing (O'Shea et al., 2012), in the particular case of the seed, more than one million tons of mango seeds are annually produced as wastes, and these are not currently utilized for any commercial purposes (Leanpolchareanchai et al., 2014). After consumption of the pulp, the mango seed endocarps are usually dumped carelessly and thereby constituting a nuisance to the environment, especially during its season.

Moringa Oleifera seeds are large and circularshaped, and grow inside the lengthy pods of the Moringa Oleifera tree (Adejumo and
Abayomi, 2012). Moringa seed pods can reach well over a foot in length and each pod can provide over a dozen large Moringa seeds. Moringa trees produce seed pods on an annual basis, much like other similar species in the plant kingdom. Moringa trees give off incredible volume of seed pods during their reproduction months. An average-sized Moringa tree of fifteen to twenty feet in height can produce hundreds or even thousands of seed pods, yielding countless Moringa seeds every year (Adejumo and Abayomi, 2012). The fresh moringa seeds have long been used by people as a tasty vegetable and when dried, it is used as water purifier because of its coagulant properties (Ayotunde et al., 2011). However, large quantities of the melon husks, moringa pod and mango endocarp are discarded and burnt, which pollute the environment. To the best of the authors' knowledge, there is no comprehensive information for the nutritional and antioxidant assessment of moringa pod and as such the study would provide not only baseline data for literature but also accord industrialists a feedstock base to make choices.

The aim of this study therefore is to determine the nutritional, phytochemical composition and antioxidant properties of melon seed husk, mango endocarp and moringa seed pod. The main objective is to evaluate their potential as possible feed ingredient for livestock.

\section{MATERIALS AND METHODS Materials}

The materials for this analysis are: Melon husk, Mango endocarp, Moringa pod. The melon husk and mango seed were sourced in Sheda village, Kwali Area Council of FCT, Nigeria. The moringa pods were obtained from the moringa plantation of Sheda Science and Technology Complex (SHESTCO), Abuja, Nigeria. All other reagents are of high analytical grade and were products of Sigma.

\section{Preparation of Samples}

The mango seed integument and seed leaf were removed from the seeds, leaving the mango endocarp. The samples (melon husk, mango endocarp and moringa seed pod) were 
air-dried for three days and pulverized to smaller particles using blender (for the melon husk) and pulverizing machine (for the moringa pod and mango endocarp). The pulverized samples were sieved, then package into air tight polythene bag and kept until when needed.

\section{Methods}

The method of AOAC (1990) was used for proximate analysis including determinations of moisture content, ash content, crude lipid, crude protein and carbohydrate.

\section{Antioxidant capacity}

The antioxidant activity was evaluated by discolouration of 2, 2-diphenyl-1-picrylhydrozyl radical (DPPH) in methanol by a slightly modified method of Brand-Williams et al. (1995). The following concentrations of the extract were tested $(0.5,0.25,0.125,0.0625$, $0.03125 \mathrm{mg} / \mathrm{ml})$. The absorbance was monitored at $517 \mathrm{~nm}$. Vitamin $C$ was used as the antioxidant standard at concentrations $(0.5$, $0.25,0.125,0.0625,0.03125 \mathrm{mg} / \mathrm{ml})$. A blank solution was prepared containing the same amount of methanol and DPPH. The radical scavenging activity was calculated using the following formula:

Inhibition $(\%)=\frac{A_{b}-A_{s}}{A_{b}} \times 100$

Where $\underline{A_{b}}=$ Absorbance of the blank

$\underline{A_{s}}=$ The absorption of the sample extract.

\section{Quantitative Phytochemical Determination}

This analysis was carried out to test for the presence and quantity of phenols (AOAC, 1995), alkaloids (Manjunath et al., 2012), tannins (Van-Burden and Robinson, 1981), flavonoids (Vabkova and Neugebauerova, 2012), saponins (Obadoni and Ochuko, 2001), Oxalate (Ukpabi and Ejidoh (1989).

\section{Determination of Gross energy}

The gross energy content was determined by calculation from fat, carbohydrate and protein contents using the Atwater's conversion factors; $16.7 \mathrm{~kJ} / \mathrm{g}(4 \mathrm{kcal} / \mathrm{g})$ for protein, $37.4 \mathrm{~kJ} / \mathrm{g}$ $(9 \mathrm{kcal} / \mathrm{g})$ for fat and $16.7 \mathrm{~kJ} / \mathrm{g}(4 \mathrm{kcal} / \mathrm{g})$ for carbohydrates and expressed in calories

(Guyot et al., 2007).

\section{Mineral analysis}

Two grams $(2 \mathrm{~g})$ of each of the samples was weighed into a beaker and $20 \mathrm{ml}$ of nitric acid was added to the sample. This was heated on the hotplate at $60^{\circ} \mathrm{C}$ for $30 \mathrm{~min}$. It was then removed from heat and allowed to cool. The solution was diluted with distilled deionized water and made up to $50 \mathrm{ml}$ in a volumetric flask. A blank was prepared in the same manner and poured into a polyproplene bottle. The samples were analysed for metals on Thermo Scientific iCE 3000AA02134104 Atomic Absorption Spectrometer using appropriate working standards (Emmanuel et al., 2016). Phosphorus was determined by vanadomolybdate colorimetric method (Ologhobo and Fetuga, 1983)

\section{Data Analysis}

All data generated were analyzed using descriptive statistic as described by Olawuyi (1996). Statistical values that were calculated include mean and standard deviation.

\section{RESULTS AND DISCUSSION}

Analysis of proximate composition provides information on the basic nutritional composition of the samples. The compositions are moisture, ash, crude fat, protein, crude fibre, and carbohydrate. These components are crucial to the assessment of the nutritive quality of the samples being analysed. The results of the proximate analysis and gross energy content are shown in Table 1. The moisture level of the samples ranged from $6.73 \%$ to $9.52 \%$. The moisture content of foods or its processed products gives an indication of its freshness and shelf life and high moisture content subjects food items to increased microbial spoilage, deterioration and short shelf life (Tressler et al., 1980; Adepoju and Onasanya, 2008). The ash content can provide an estimate of the mineral content of a product. The values of the ash content of the samples range from $3.59 \%$ to $7.69 \%$ which may be an indication of high mineral content of the samples. The ash content of samples is similar 
to a range of ash content values reported by Adeyi (2010) for some agricultural wastes. The result shows that the agriculture wastes are high in crude fibre (Mango endocarp, 49.47\%; Melon seed husk, 51.61\%; Moringa pod, $58.10 \%$ ), comparably higher than coconut husk, cocoa pods, kola nut pod, plantain wastes flour reported by Adeyi (2010) and Okareh et al. (2015). High fibre content in diets have been reported to result in increased removal of carcinogens, potential mutagens, steroids, bile acids and xenobiotics by binding or absorbing to dietary fibre components and be rapidly excreted, hence these wastes will have health promoting benefits for the ruminants and non-ruminants (Ayoola and Adeyeye, 2009). Thus, the high fibre content of the samples may make them desirable to be used as components in feed formulation. The result showed that melon husk has the highest amount of crude protein (12.22\%), moringa pod $(7.4 \%)$ and mango endocarp (3.45\%). The appreciable amount of crude protein of the samples, especially melon seed husk, indicates that they could be preferably used as source of protein for animal feed enrichment and or formulation. Protein is an essential component of diet needed for survival of animals and human beings, their basic function in nutrition is to supply adequate amount of required amino acids. Protein deficiency causes growth retardation, muscle wasting, oedema, abnormal swelling of the belly and collection of fluids in the body (Mounts, 2000). The proximate analysis results of melon seed husk obtained from this research work are in agreement with the study by Abdulrazaq et al. (2014) who reported a similar range of values. In livestock diets, energy is one of the most expensive nutritional components of feed formulation.
The amount of gross energy content is shown in Table 1 with melon husk having the highest energy content (245.69J). This may be due, in part, to the high lipid content of the samples as lipids have been shown to be concentrated energy source, inclusion of lipids is known to affect growth rate and feed efficiency (Brian et al., 2015). The presence of appreciable quantity of energy in the samples in this study may make them fit for consideration in formulation of poultry and animal feeds in general as sources of energy.

Table 2 shows the mineral composition of the test samples. The results of mineral analysis showed the presence of calcium, Ca (6.14 $\mathrm{mg} / \mathrm{kg}-243.95 \mathrm{mg} / \mathrm{kg})$, phosphorus, $\mathrm{P}(24.25$ $\mathrm{mg} / \mathrm{kg}-106.70 \mathrm{mg} / \mathrm{kg}$ ); Magnesium, Mg (13 $\mathrm{mg} / \mathrm{kg}-61.44 \mathrm{mg} / \mathrm{kg})$; iron, Fe $(3.60 \mathrm{mg} / \mathrm{kg}-$ $29.32 \mathrm{mg} / \mathrm{kg}) ;$ zinc, Zn (0.17 mg/kg-0.70mg/kg). The presence of cobalt, nickel and copper are negligible in all the samples. From the results obtained, moringa pod possess the highest amount of calcium and magnesium (243.95 $\mathrm{mg} / \mathrm{kg}$ and $61.44 \mathrm{mg} / \mathrm{kg}$ respectively). The result also showed that melon husk possessed the highest amount of iron $(21.26 \mathrm{mg} / \mathrm{kg})$. The presence of these essential nutrients and minerals imply that the samples from this study could be utilized as sources of essential nutrients in feed ingredients for livestock. Minerals, which are essential nutrients are said to be present in small amounts in the body or in several parts per million (Gafar and Itodo, 2011). They are essential because each of them plays important role in metabolic processes of the body and their absence can cause deficiency symptoms in animals (McDonald et al., 1995; Gafar and Itodo, 2011).

Table 1: Proximate composition of test samples and Gross energy content

\begin{tabular}{cccccccc}
\hline Sample & $\begin{array}{c}\text { Moisture } \\
\text { content } \\
(\mathbf{g} / 100 \mathrm{~g})\end{array}$ & $\begin{array}{c}\text { Ash } \\
\text { content } \\
(\mathbf{g} / 100 \mathrm{~g})\end{array}$ & $\begin{array}{c}\text { Crude Protein } \\
(\mathbf{g} / \mathbf{1 0 0 g})\end{array}$ & $\begin{array}{c}\text { Crude Lipid } \\
(\mathbf{g} / \mathbf{1 0 0 g})\end{array}$ & $\begin{array}{c}\text { Crude Fibre } \\
(\mathbf{g} / 100 \mathrm{~g})\end{array}$ & $\begin{array}{c}\text { Carbohydrate } \\
(\mathbf{g} / 100 \mathrm{~g})\end{array}$ & $\begin{array}{c}\text { Gross Energy } \\
(\mathrm{J})\end{array}$ \\
\hline $\begin{array}{c}\text { Melon } \\
\text { husk }\end{array}$ & $8.49 \pm 0.04$ & $3.59 \pm 0.05$ & $12.22 \pm 0.25$ & $20.09 \pm 0.28$ & $51.61 \pm 0.27$ & $4.00 \pm 0.23$ & $245.69 \pm 4.40$ \\
$\begin{array}{c}\text { Moringa } \\
\text { pod } \\
\text { Mango }\end{array}$ & $9.52 \pm 0.07$ & $5.08 \pm 0.09$ & $7.40 \pm 0.11$ & $11.75 \pm 0.31$ & $58.10 \pm 0.14$ & $8.15 \pm 0.17$ & $167.95 \pm 3.91$ \\
endocarp & $6.73 \pm 0.15$ & $7.69 \pm 2.22$ & $3.45 \pm 0.18$ & $9.41 \pm 0.25$ & $49.47 \pm 0.32$ & $23.25 \pm 0.23$ & $191.49 \pm 3.80$ \\
\hline
\end{tabular}

${ }^{*}$ Data are mean values \pm standard deviation (SD) of triplicate results 
Nigerian Journal of Basic and Applied Science (December, 2018), 26(2): 35-44

Table 2: Mineral composition of samples ( $\mathrm{mg} / \mathrm{kg}$ )

\begin{tabular}{ccccccccc}
\hline Sample & Iron & Magnesium & Calcium & Zinc & Copper & Manganese & Nickel & Phosphorus \\
\hline $\begin{array}{c}\text { Melon } \\
\text { husk }\end{array}$ & 21.28 & 52.26 & 14.94 & 0.7 & 0.16 & 1.15 & 0.00 & 106.70 \\
$\begin{array}{c}\text { Moringa } \\
\text { pod }\end{array}$ & 3.60 & 61.44 & 243.95 & 0.35 & 0.03 & 1.22 & 0.00 & 33.75 \\
$\begin{array}{c}\text { Mango } \\
\text { endocarp }\end{array}$ & 29.32 & 13.00 & 6.14 & 0.17 & 0.00 & 1.59 & 0.00 & 24.25 \\
\hline
\end{tabular}

The essential mineral elements of nutritional importance are the macro (major) elements such as $\mathrm{Ca}, \mathrm{P}, \mathrm{K}, \mathrm{Na}$, and $\mathrm{Mg}$. The micro (trace) elements are $\mathrm{Fe}, \mathrm{Zn}, \mathrm{Cu}, \mathrm{Mn}$, and $\mathrm{Co}$ (Ogbe and George, 2012).

Calcium and phosphorus are very important in the formation of strong bones and teeth, for growth, normal nerve and muscle action, blood clotting, heart function and cell metabolism (Roth and Townsend, 2003; Rolfe et al., 2009). Some minerals are required for normal body growth, activities of muscles and skeletal development (such as calcium), cellular activity and oxygen transport (copper and iron), chemical reaction in the body and intestinal absorption (magnesium), as well as the regulation of acid-base balance (phosphorus). Iron is useful in prevention of anaemia and other related diseases (Oluyemi et al., 2006). Manganese plays a role in energy production and in supporting the immune system (Muhammad et al., 2011). It also works with vitamin $\mathrm{K}$ to support blood clotting, and with $\mathrm{B}$ complex vitamins to control the effects of stress (Muhammad et al., 2011). Zinc is useful for protein synthesis, normal body development and recovery from illness (Muhammad et al., 2011). Results from this study also show that the samples contain some of the antioxidant minerals such as $\mathrm{Ca}, \mathrm{Zn}$ and $\mathrm{Mn}$ which are important for antioxidant enzymes in vivo and hence protect the body from diseases caused by oxidative stress such as cancer. This is in agreement with the report of Elsayed and Amany (2016). The result of macro elements of mango endocarp in this study is also in range with that reported by Elegbede et al. (1995) and Odunsi (2005).

Figure 1 shows the DPPH scavenging capacity of the samples. Mango endocarp displayed the highest antioxidant capacity (53.61\%-85.37\%);
Melon seed husk (-6.16\%-35.65\%); Moringa pod $(10.79 \%-43.80 \%)$. The antioxidant assay was carried at a concentration range of $0.03125 \mathrm{mg} / \mathrm{ml}-0.5 \mathrm{mg} / \mathrm{ml}$ of the samples ethanolic extract. Almost all chronic diseases are associated with the danger of free radicals, which are also considered a cause of advanced aging (Mustafa et al., 2010). The free radical scavenging assay is the most widely used analysis in evaluating antioxidant activity in phytochemistry. It is a simple and rapid test that is based on the reaction rate between a stable free radical, 2, 2-diphenyl-2-pycrylhydrazyl (DPPH) and antioxidants. The availability of DPPH radicals commercially is another reason for its broad utilization (Paixão et al., 2007). Historically, antioxidants have been added to commercial feeds to prevent lipid peroxidation and oxidative rancidity during production, processing and storage of feeds. More importantly, the current trend of formulating diets with polyunsaturated fatty acids (PUFAs)rich ingredients has heightened the use of antioxidants in animal feeds. Indeed, PUFA-rich foods and feeds are highly susceptible to lipid peroxidation (Decker et al., 2012). The samples in this study may not only serve as source of antioxidant for preservation of animal feeds but a natural source of antioxidants in keeping the livestock in good health, as natural antioxidants have been shown to possess broad spectra of biological actions, including pharmacological and therapeutic activity against free radicals and oxidative stress (Bagchi et al., 2000). The result on mango endocarp antioxidant activity obtained in this study is in agreement with reports by Saito et al. (2008) and Abdullah et al. (2014) that mango seed endocarp possess powerful antioxidants of high antioxidant capacity. Mango endocarp was also shown to compete favourably with the standard (Ascorbic acid) used in the study. 


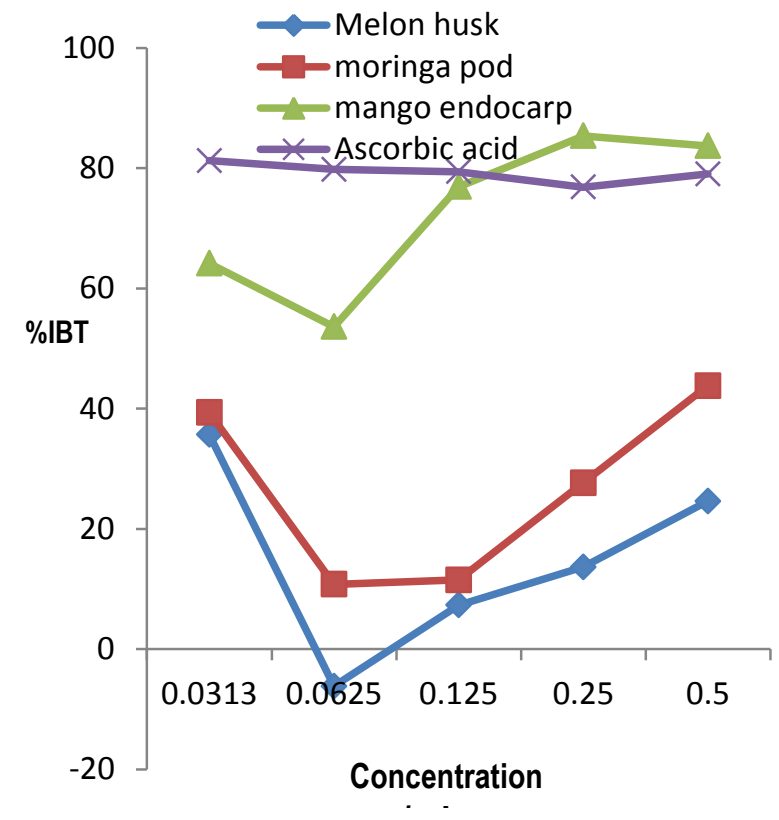

IBT = Inhibition

Figure 1: DPPH free radical scavenging activities of Melon husk, Moringa pod and Mango endocarp

The result of the antinutrient screening of the samples is shown in Table 3. Antinutrients are compounds that limit the wide use of many plants due to their ubiquitous occurrence. They are compounds capable of eliciting deleterious effect in man and animals (Kubmarawa et al., 2008). The presence of these anti nutrients, especially in high quantity reduces the bioavailability of nutrients in the food and plants (Akindahunsi and Salawu, 2005). Oxalate for example tends to render calcium unavailable by binding to the calcium ion to form complexes (calcium oxalate crystals). These oxalate crystals formed prevents the absorption and utilization of calcium. The calcium crystals may also precipitate around the renal tubules thereby causing renal stones (Ladeji et al., 2004). The amount of oxalate in the samples was negligible.

Tannin was not detected in melon husk and moringa pod, while mango endocarp contained $0.52 \%$ tannin (Table 3 ). Tannins are plant polyphenols, which have ability to form complexes with metal ions and with macromolecules such as protein and polysaccharides (Dei et al., 2007). Excess of consumptions of tannins in human could be toxic (Ferreira et al., 2008). This is because tannins are metal ions- chelators and tannin-chelated metal ions are not bioavailable hence could decrease the bioavailability of iron leading to anaemia.

The saponin content of melon husk $(0.014 \%)$, moringa pod $(0.014 \%)$ is negligible while it was not detected in mango endocarp. Saponins are glucosides, which includes steroid saponins and triterpenoid saponins (Dei et al., 2007). Saponin in excess could cause hypocholestrolanemia because it binds cholesterol making it unavailable against red blood cell (Khahlil and Eladomy, 1994). Saponin-protein complex formation can reduce protein digestibility (Shimoyamada et al., 1998). The presence of saponin in the body can help to fight infection and microbial inversion (Sodipo et al., 2000). High levels of saponins in feed affect feed intake and growth rate in poultry (Dei et al., 2007).

Table 3: Phytochemical/Antinutrient activity of Melon husk, Moringa pod and Mango endocarp

$(\%)$

\begin{tabular}{lccc}
\hline Constituents & $\begin{array}{l}\text { Melon } \\
\text { husk }\end{array}$ & $\begin{array}{l}\text { Moringa } \\
\text { pod }\end{array}$ & $\begin{array}{l}\text { Mango } \\
\text { endocarp }\end{array}$ \\
\hline Alkaloids & 0.26 & 0.17 & 0.25 \\
Flavonoids & 0.38 & 0.38 & 0.33 \\
Tannins & ND & ND & 0.52 \\
Saponin & 0.01 & 0.01 & ND \\
Phenols & ND & ND & 0.09 \\
Oxalate $\left(10^{-6}\right)$ & 6.55 & 6.55 & 6.55 \\
\hline
\end{tabular}

ND- Not detected

Alkaloid content of the samples is: melon husk $(0.26 \%)$, moringa pod $(0.17 \%)$ and mango endocarp (0.25\%). Despite the medical uses of alkaloids, they cause gastrointestinal upsets and neurological disorders (Ogbuagu, 2008).

The antinutrient components of the samples in this study were very low in concentration; this is in agreement with report of antinutrient content of melon husk by Ogbe and George (2012). The presence of nutrients, such as protein, fibre and lipid, in appreciable quantity in the samples in this study implies they could be utilized as feed ingredient in poultry diets. Nutrients are known to improve the performance and health of birds. Nutrients are 
required for proper bone development and improved eggs quality (Ogbe and George, 2012).

\section{CONCLUSION}

The results of the samples analysed in this study indicate that the agricultural wastes could serve as potential ingredient in formulation of feedstock for animal feed. This is shown in the high level of fibre, considerable quantity of crude protein, carbohydrate, crude fibre, ash content, crude lipid and low levels of antinutrients factors. The results also showed that the samples contain some of the antioxidant minerals such as $\mathrm{Ca}, \mathrm{Zn}$ and $\mathrm{Mn}$ which are important for antioxidant enzymes in vivo and hence could protect the body from diseases caused by oxidative stress.

Thus, rather than been allowed to constitute environmental pollutants, they (melon husk, mango endocarp and moringa pod) may be used as nutritive components in formulation of animal feeds.

\section{REFERENCES}

Abdullah, H., Mohammed, A., and Abdullah, R. (2014). Cytotoxic effects of Mangifera indica L. kernel extract on human breast cancer (MCF-7 and MDA-MB231 cell lines) and bioactive constituents in the crude extract. BMC Complementary and Alternative Medicine, 14,199.

Abdulrazak, S., Otie, D. and Oniwapele, Y.A. (2014). Proximate Analysis and AntiNutritional Factors of Groundnut and Melon Husk. Online Journal of Animal and Feed Research,4(2): 25-28.

Adelagun, R.O.A., Berezi, E.P., Itodo, A.U., Oko, O.J., Kamba, E.A., Andrew, C. and Bello, H.A. (2014). Adsorption of $\mathrm{Pb}$ from aqueous solution by modified melon (Citrulluslanatus) seed husk. Chemistry and Materials Research,6(2): 2014.

Adejumo, B.A. and Abayomi, D.A. (2012). Effect of Moisture Content on Some Physical Properties of Moringa Oleifera Seed. IOSR Journal of Agriculture and Veterinary Science. 1(5): 12-21.
Adepoju, O.T. and Onasanya L.O. (2008). Nutrient composition and antinutritional factors of Dialium guineense Wild fruit pulp. Ife. Journal of Nutritional Science, 10 (1): 33-37.

Adeyi, O. (2010). Proximate composition of some agricultural wastes in Nigeria and their potential use in activated carbon production. Journal of Applied Sciences and Environmental Management, 14 (1): 55 - 58.

Akindahunsi, A.A. and Salawu, S.O. (2005). Phytochemical screening of nutrient and antinutrient composition of selected tropical green leafy vegetables. African Journal of Biotechnology, 4: 497-501.

AOAC (1990).Official Methods of Analysis $4^{\text {th }}$ edition, Association of Official Analytical Chemists, Washington DC.

AOAC (1995). Official methods of analysis (16th edn) Association of Official Analytical Chemists. Arlington, V. A. USA.

Ayoola, P.B. and Adeyeye, A. (2009). Proximate Analysis and Nutrient Evaluation of Some Nigerian Pawpaw Seeds Varieties. Science Focus, 14 (4): 554-558.

Ayotunde, E.O., Fagbenro, O.A. and Adebanyo, O.T. (2011). Toxicity of aqueous extract of Moringa olifera seed powder to Nile tilapia (Oreochromis niloticu) fingerlings. International Research Journal of Agricultural Science and Soil Science, 1:142-150

Bagchi, D., Bagchi, M., Stohs, S. J., Das, D. K., Ray, S. D. Kuszynski, C. A., Joshi, S.S. and Pruess, H.G. (2000). Free radicals and grape seed proanthocyanidin extract: Importance in human health and disease prevention. Toxicology, 148 (2-3), 187-197.

Bally, I.S.E. (2006). Mangifera indica (Mango) Ver, 3.1. In: Elevitch, C.R. (ed). 'Species profiles for pacific Island Agroforestry'. Permanent Agricultural Research (PAR). Holualoa, Hawaii. 
Retrieved

from http//www.traditionaltree.org.

Brand-Williams, B., Cuvelier, M.E., Berset, C., 1995. Use of a free radical method to evaluate antioxidant activity. LWTFood Science and Technology, 28, 2530.

Brian, J.K., Trey, A.K. and Gerald, C.S. (2015). Characteristics of lipids and their feeding value in swine dietsJournal of Animal Science, 6 (1):30.

Decker, E.A., Akoh, C.C. and Wilkes, R.S. (2012). Incorporation of (n-3) fatty acids in foods: challenges and opportunities. The Journal of Nutrition, 142, 610-613.

Dei, H.K., Rose S.P. and Mackenzie, A.M. (2007). Shea nut (Vitellaria paradoxa) meal as a feed ingredient for poultry, World's Poultry Science Journal, 63 (4), 611624

Elegbede, J., Achoba, I., and Richard, H. (1995). Nutrient composition of mango (Mangnifera indica) seed kernel from Nigeria. Journal of Food Biochemistry, 19 (5): 391-398.

Elsayed, E. and Amany, S. (2016). Evaluation of nutritional value and antioxidant activity of tomato peel extracts. Arabian Journal of Chemistry, 9: S1010-S1018

Emmanuel, S. A, Olajide, O., Abubakar, S., Akiode, S.O. and Etuk-Udo, G. (2016). Chemical Evaluation, Free Radical Scavenging Activities and Antimicrobial Evaluation of the Methanolic Extracts of Corn Silk (Zea mays). Journal of Advances in Medical and Pharmaceutical Sciences, 9(4): 1-8

FAO. (2004). FAO Products Year report. Food and Agricultural Organization, Rome.

Ferreira, D., Gross, G.G, Hagerman, A.E., Kolodzied, H. and Yoshida, T. (2008). Tannins and related polyphenols: perspective G. Their chemistry, biology, ecological effects and human health protection. Photochemistry, 69: 3006-3008

Gafar, M.K. and Itodo, A.U. (2011). Proximate and mineral composition of hairy indigo leaves.Electronic. Journal of
Environmental, Agricultural and Food Chemistry, 10(3): 2007-2018.

Guyot, J.P., Rochette, I., Treche, S. (2007). Effect of fermentation by amylolytic lactic acid bacteria, in process combinations, on characteristics of rice/soybean slurries: a new method for preparing high energy density complementary foods for young children. Food Chemistry. 100:623663.

Kubmarawa, D., Andanyan, I.F.H. and Magoniya, A.M. (2008). Amino acid profile of two non-conventional leafy vegetables. Sesanus Indium and Batanite aegyptica. African Journal of Biotechnology, 7(18): 3502-3504.

Ladeji, O., Akin. C.U. and Umaru, H.A (2004). Level of phytochemicals factors in vegetable commonly eaten in Nigeria. African Journal of Natural Science, 7: 71-73.

Leanpolchareanchai, J., Padois, K., Falson, F., Bavovada, R. and Pithayanukul, P. (2014). Microemulsion system for topical delivery of thai mango seed kernel extract: Development, physicochemical characterisation and ex-vivo skin permeation studies. Molecules, 19(11): 17107-17129.

Manjunath, A., Mahadev, B.G. and Shradda, U.N. (2012). Estimation of total alkaloid in Chitrakadivati by UVSpectrophotometer. Ancient Science of Life, 31(4):198-201.

Masibo, M. and He, Q. (2009). Mango bioactive compounds and related nutraceutical properties-a review. Food Reviews International, 25(4), 346-370.

McDonald, P., Edward, R.A., Greenhalti, F.D. and Morgan, C.A. (1995). Animal Nutrition, Prentices Hall, London, 101122

Moerman, D., (1998). Native American Ethnobotany, Timber press, Oregon, 453-459

Morton, J.F. (1987). Mango. In: Fruits of warm climate (mango) 221-239. Miami Webster. 
Mounts, T.L. (2000). The Chemistry of Components. (2nd edn) Royal Society of Chemistry.

Muhammad, A., Dangoggo, S.M., Tsafe, A.I., Itodo, A.U. and Atiku, F.A. (2011). Proximate, minerals and antinutritional factors of Gardenia aqualla (Guadendutse) fruit pulp, Pakistan Journal of Nutrition, 10(6): 577-581.

Mustafa, R.A., Hamid, A.A., Mohamed, S. and Abubakar, F. (2010). Total phenolic compounds, flavonoids, and radical scavenging activity of 21 selected tropical plants. Journal of Food Science, 75: C28-C35.

Mutayoba, S.K., Dierenfield E., Mercedes V.A., Frances, Y. and Knight, C.D. (2011). Determination of chemical composition and anti-nutritive components for Tanzanian locally available poultry feed ingredients. International Journal of Poultry Science, 10(5): 350-357.

Obadoni, B.O. and Ochuko, P.O. (2001). Phyto-chemical studies and comparative efficacy of the crude extract of some homeostatic plants in Edo and Delta states of Nigeria. Global Journal of Pure and Applied Sciences, 8: 203-208.

Odunsi, A. (2005). Response of laying Hens and growing broilers to the dietary inclusion of mango (Mangifera indica L.) seed kernel meal. Tropical Animal Health and Production, 37(2): 139-150

Ogbe, A.O. and George, G.A.L. (2012). Nutritional and Anti-nutrient Composition of Melon Husks: Potential as Feed Ingredient in Poultry Diet. Research Journal of Chemical Science, 2(2): 35-39.

Ogbuagu, M.N. (2008). Nutritive and antinutritive composition of the wild (inedible) species of Dioscorea bulbifera (potato yam) and Dioscorea dumentorum (bitter yam). The Pacific Journal of Science and Technology. 9: 203- 207

Okareh, O.T., Adeolu, A.T. and Adepoju, O.T. (2015). Proximate and mineral composition of plantain (Musa
Paradisiaca) wastes flour; a potential nutrients source in the formulation of animal feeds. African Journal of Food Science and Technology, 6(2): 53-57.

Olawuyi, J.F. (1996). Biostatistics: A foundation course in health sciences. 1st Edition. University College Hospital, Published by Tunji Alabi Printing Co. Total Garden, Ibadan, Nigeria, 1-221

Oluyemi, E.A., Akilua, A.A., Adenuya, A.A. and Adebayo, M.B. (2006). Mineral contents of some commonly consumed Nigerian foods. Science Focus, 11: 153-157

Ologhobo, A.D. and Fetuga, B.L. (1983). Investigation on the trypsin inhibitor, hemagglutinin, phytic and tannic acid contents of cowpea Vigna Unguiculata. Food Chemistry, 12 (4): 249-254.

O'Shea, N., Arendt, E. and Gallagher, E. (2012). Dietary fibre and phytochemical characteristics of fruit and vegetable by-products and their recent applications as novel ingredients in food products. Innovative Food Science \& Emerging Technologies, 16: 1-10.

Paixão, N., Perestrelo, R., Marques, J.C. and Câmara, J.S. (2007). Relationship between antioxidant capacity and total phenolic content of red, rosé and white wines. Food Chemistry, 105: 204-214.

Ribeiro, S. and Schieber, A. (2010). Bioactive compounds in mango (Mangifera indica L.). Bioactive Foods in Promoting Health, 34, 507-523.

Rolfes, S.R., Pinna, K., Whitney, E. (2009). Understanding Normal and Clinical Nutrition. 8th Edn Wadsworth Cengage Learning, pp. 383.

Roth, A.R. and Townsend, C.E. (2003). Nutrition and diet therapy 8 edn. Delmar Learning, Thomson Learning Inc. Canada, pp.132.

Saito, K., Kohno, M., Yoshizaki, F. and Niwano, Y. (2008). Extensive screening for edible herbal extracts with potent scavenging activity against superoxide anions. Plant Foods for Human Nutrition, 63(2): 65-70. 
Seifu, Z. (2010). 'Production and quality evaluation of spray dried fruit products'. A Master of Science thesis Presented to the School of Postgraduate Studies, University of Addis Ababa, Ethiopia.

Shimoyamada, M., Ikedo, S., Dotsubu, R. and Watanaba, K. (1998). Effects of soyabeans saponins on chymotrptic hydrophyse chem. 46, 4793-4797.

Sodipo, O.A. Akiriyi, Y.A. and Ogunbanosu, Y.U. (2000). Studies on certain characteristics of extracts or barks of pansinystalia macruceras (K. Schem) piere, exbeila, Glob. Pansinystalia macruceras, 6: 83-78.

Tressler, D.K., Van Arsdel, W.B. and Copley, M.J. (1980). The freezing preservation of foods. $4^{\text {th }}$ Edn, 23, AVI Publishing Co. Westport, Conn

Ukpabi, V.J. and Ejidoh, J.I. (1989). Effect of deep out frying on the oxalate content and the degree of itching of cocoyams. (Xanthosoma and colocassia spp).
Technical paper presented at the 5th annual conference of the Agriculture society of Nigeria. Federal University of Technology Owerri, Nigeria, 3- 6.

Vabkova, J. and Neugebauerova, J. (2012). Determination of total phenoliccontent, total flavonoid content and FRAP in culinary herbs in relation to harvest time. Acta Universitatis Agriculturae Et Silviculturae Mendelianae Brunensis; LX (1):167-172.

Van-Burden, T.P. and Robinson, E.C. (1981). Formation of Complexes between proteins and tannin acid. Journal of Agricultural and Food Chemistry, 1: 77 $-82$.

Yusuf, S.A. and Salau, A.S. (2007). Forcasting Mango and Citrus Production in Nigeria. Munich Personal RePEc Archive. Retreived from http//mpra.ub.unimuenchem.de/2691/M PRA paper No. 2691. 